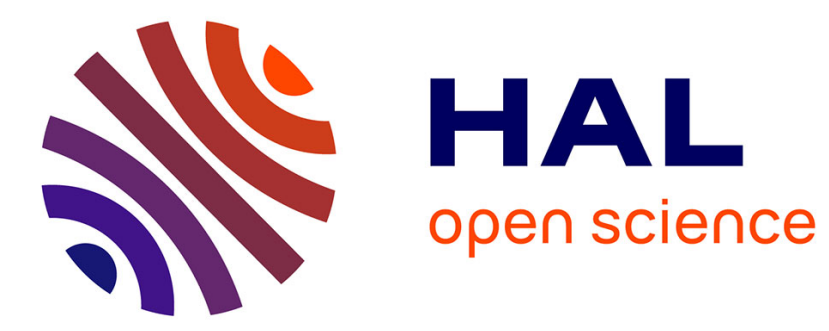

\title{
Helping People help themselves
}

Jody Sindelar, Elizabeth Beasley

\section{To cite this version:}

Jody Sindelar, Elizabeth Beasley. Helping People help themselves: Insights from behavioral economics for policies to counter addiction. LIEPP Policy Brief, 2014, 15, 10.25647/liepp.pb.15 . hal-03393006

\section{HAL Id: hal-03393006 \\ https: / hal-sciencespo.archives-ouvertes.fr/hal-03393006}

Submitted on 21 Oct 2021

HAL is a multi-disciplinary open access archive for the deposit and dissemination of scientific research documents, whether they are published or not. The documents may come from teaching and research institutions in France or abroad, or from public or private research centers.
L'archive ouverte pluridisciplinaire HAL, est destinée au dépôt et à la diffusion de documents scientifiques de niveau recherche, publiés ou non, émanant des établissements d'enseignement et de recherche français ou étrangers, des laboratoires publics ou privés.

\section{다(1) (2)}

Distributed under a Creative Commons Attribution - ShareAlikel 4.0 International 


\title{
pIEPPlicybrief
}

\section{Helping people help themselves:}

\author{
Insights from behavioral economics for
}

\author{
policies to counter addiction
}

Jody Sindelar

jody.sindelar@yale.edu

Jody Sindelar is a health economist and professor at the Yale School of Public Health, and was a visiting Professor at Sciences Po in September 2014. She is also affiliated with NBER and IZA. She is a founding member and has served as President of the American Society of Health Economists.

Elizabeth Beasley

elizabeth.beasley@sciencespo.fr

Elizabeth Beasley is an affiliate of LIEPP, and has a PhD in Economics from Sciences Po. She has also worked as a consultant for the World Bank and was formerly the head of J-PAL Europe.

\section{RÉSUMÉ}

Les apports de l'économie comportementale permettent de concevoir de nouvelles formes d'action publique et d'augmenter l'efficacité des recommandations habituelles. Nous discutons ici de l'utilité de ces approches pour traiter la toxicomanie. Ces modèles reposent sur les biais cognitifs intervenant dans la prise de décision pour aider les gens à éviter de commettre des erreurs. Des exemples de ces stratégies consistent à modifier la présentation de l'information, à transformer les incitations, et à offrir des possibilités de pré-engagement. Il est essentiel de tester rigoureusement ces différentes stratégies avant de les mettre en pratique.

\section{ABSTRACT}

Insights from behavioral economics have the potential to generate novel interventions and polices as well as increase the effectiveness of standard prescriptions. Here we discuss approaches to address addictions. These insights hinge on leveraging decisionmaking biases to help people overcome mistakes. Examples of these strategies include changing the presentation of information, restructuring incentives, and providing opportunities for precommitment. Rigorously testing different policy ideas is key to putting them into practice.

\section{Introduction}

Behavioral economics combines insights from psychology and economics to take systematic biases into account when analyzing decision-making by individuals. Neoclassical economics ignores many of these biases to make analysis of economic decisions will be more tractable. But behavioral economics recognizes that some decisions are systematically more likely to suffer from biases, and that taking these biases into account will likely make public policies more effective (World Bank, 2015). This policy brief examines some new frontiers in behavioral economics that can be applied to addiction policy

\section{Tempting Goods}

One area where systematic biases are

* Les auteurs adbèrent à la charte de déontologie du LIEPP, disponible en ligne, et n'ont déclaré aucun conflit d'intérêt potentiel. consume. In contrast, for most goods, selfcontrol is not a key factor. Self-control is not needed to avoid consuming too many pencils or glasses of water, for example.

Addictive substances and activities are special cases of tempting goods. Addictive substances can produce a compulsion to use more of the goods over time. Addicts can develop tolerance and withdrawal symptoms when they try to quit or cut-down. Some addictive substances can result in serious physical, neurological, psychological and social harm. Addiction is not limited to substances but can extend to activities as well. For example, compulsive gamblers also exhibit signs of addiction.

Addicts continue to consume more of the addictive substance than they say they want to. For example, many smokers in the United States say they want to quit, many try to quit, and some succeed only to restart smoking. In the morning, people want to drink less, but at happy hour they 
are unable to resist temptation, and then when they get home they regret what they did. One way to think about these 'two minds' of addiction is that people have "Hot" and "Cold" periods: a cold, slow, deliberative period, versus a hot, fast, instinctual period. They may decide, in the "cold" period, that they want to reduce consumption, but when they find themselves in a "hot" period, perhaps due to external cues, they are unable to resist (Bernheim \& Rangel, 2004).

\section{Neoclassical and Behavioral Economics and Public Policy}

According to neoclassical economics, one justification for government intervention is a market failure. In the case of addiction, there are two key potential market failures: imperfect information and externalities. There are standard policy prescriptions for both of these market failures. These policies are often at least partially effective, but there are gaps in their effectiveness that might be filled by ideas from behavioral economics.

There are two insights from behavioral economics that are particularly important in the case of addiction: imperfect information processing and limited self-control. Imperfect information processing means that people do not and cannot notice and objectively process all of the information available to them. Thus people use rules to simplify the process, but this can lead to systematic biases.

Self-control limitations are modeled in economics as time-inconsistency or hyperbolic discounting. Both perspectives yield, for example, that the optimal time to start a diet is always "tomorrow" - but tomorrow never arrives. Psychologists might consider self-control to be something akin to willpower. In the both disciplines, the concept is critical in many decisions.

Figure 1: Percent of GDP spent on tobacco-related illness: One dimension of externalities of tobacco use is spending on healthcare for those suffering from tobacco-related illnesses. For some countries, this burden is quite high. Sources: GDP, 2010: World Development Indicators, World Bank. Estimates of both private and public direct medical costs of treating tobacco-related illnesses: Eriksen et al, 2012.

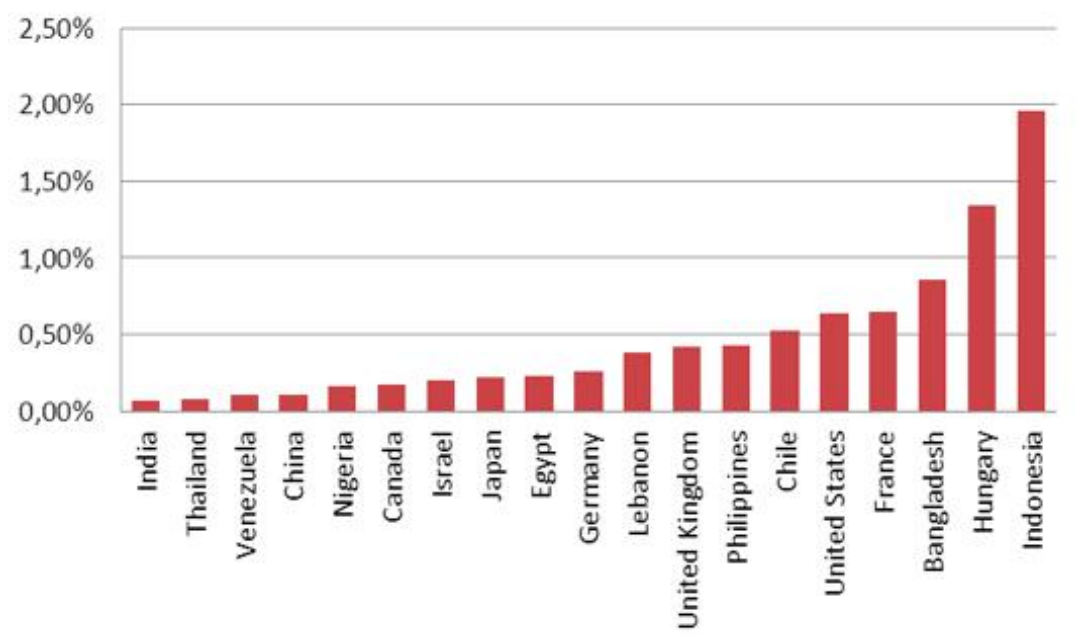

\section{Information}

\section{Neoclassical Economics and Information}

Neoclassical economics is sensitive to the problem of imperfect information: if people do not have good information, they will not be able to reach their preferred choices. Imperfect information justifies a policy of improving information on the harms of drug consumption and requiring truth in advertising.

\section{Behavioral Economics and Information}

In addition to considering whether information is available, behavioral economics takes into account that people do not absorb and process available information perfectly. Thus behavioral economics is concerned with making information salient, motivating and easy to use.

Recent studies from the fields of psychology and economics have shown that framing can be very important. Framing is changing the perspective with which people approach a choice. For example, people may make a different choice depending on whether an option is described as a gain or a loss, while the magnitude of the option remains the same. In the context of addiction, a message that seeks to persuade people not to smoke emphasizing the health benefits from quitting may be more (or less) powerful than the message emphasizing health losses of not quitting. Alternatively, the message could shift the frame entirely by emphasizing financial benefits, increasing people's attention to the message (Sindelar and O’Malley, 2014).

Some studies have shown that reminders (for example, through text messaging) can be helpful when people are trying to change their behavior (e.g., see Free et al, 2011). In the case of addiction, sending targeted, salient, reminders may help people resist the temptation of an addictive good.

\section{Incentives}

\section{Neoclassical Economics and Incentives}

Externalities occur when the cost (or benefit) of an action is borne (or enjoyed) at least in part by someone who is not taking the action. For example, a negative externality of smoking is that the smoke harms those nearby and increases their respiratory problems through passive smoke. Figure 1 shows the cost of health care for tobacco-related illnesses as a percent of GDP for selected countries. The standard neoclassical economics policy prescription for externalities is to "internalize the externality" by taxing to increase the cost to consumers of a harmful good or action; or subsidizing to decrease the cost of a beneficial good or action, like quitting. Thus 
countries often impose high taxes on cigarettes and alcohol, and provide free (subsidized) resources for those trying to quit. However these policies produce gaps - in particular, high taxes may not stop those smokers with severe selfcontrol problems from smoking. Thus some people with low self-control are harmed - rather than helped - by a tax as they continue to smoke but pay more. As those with low income are more likely to smoke, at least in the U.S., this can have adverse distributional impacts (Remler, 2004).

\section{Behavioral Economics and Incentives}

Behavioral economics builds on and improves the neoclassical intervention of incentives by focusing on the salience, structure, timing, and delivery mechanism of the incentive. A series of studies has found that quite small financial payments can have a very large effect on drug users' and smokers' ability to quit if they are carefully structured. This is especially impressive when one considers that, given the benefits of quitting, a sophisticated addict could "pay" herself to quit. Behavioral economics gives several ideas on how policymakers might increase the effectiveness of incentives:

i. Increase the salience: A tax's salience (not just the size) changes how well it will work: People may not respond to incentives if they do not notice them, so if the tax is highly visible, it may work better to change behavior (Chetty et al., 2009).

ii. Use lotteries: People have a tendency to overweight low probability outcomes. This means, for example, that people may respond more to a $5 \%$ chance of winning $\$ 100$ than getting $\$ 5$ for sure (even though the expected value is the same). Therefore, for a fixed budget available to spend on incentives, offering incentives on a probabilistic basis may be more effective per dollar.

iii. Take advantage of loss aversion: Loss aversion is a bias where people feel worse when they lose something they already have than when they miss an opportunity to win the same thing. That is, people tend to be more motivated to avoid losing $\$ 10$ than by prospect of gaining $\$ 10$. This bias can be incorporated into an incentive structure to make the incentive more effective (Alessi and Petry, 2014). Regret has also been used in lotteries to increase compliance with weight-loss regimes. Those trying to lose weight are entered into a lottery in which a name is draw for the price, but if the winning person has not completed the weight lose activity required for a prize, she forfeits the prize This approach has been shown to be effective in weight lose and adherence to medication; they may also be effective in structuring incentives for quitting addictive behavior (Volpp et al, 2008). iv. Provide immediate benefits: People tend to be present-biased and time inconsistent, so they will put off the pain of quitting until tomorrow, but tomorrow never comes. Because the benefits of quitting are greatest in the future, providing incentives earlier - even small ones - can help encourage people to take their desired action earlier. Thus incentives that are contingent on the process of quitting in addition to paying on the outcome, might be helpful.

\section{New and Different Tools from Behavioral Economics}

Some of the most interesting approaches from behavioral economics are absent from, and even contradictory to, neoclassical economics. Precommitment devices allow people to prevent their 'future selves' from making the decision that they now wish that would not make in the future. This voluntary commitment occurs in a "Cold" present period and it binds the future self from making more rash decisions in a future "Hot" period. In order to make the commitment, the person must realize his own self-control problem. The naïve person will think he will be able to resist the temptation even though she has failed before.

Addicts can pre-commit by taking action today to prevent future addictive behavior (or at least make it very difficult). The Voluntary Exclusion Programs for gamblers is a good example. A compulsive gambler can put her name on a 'no-entry' list at a casino during a "Cold" period, so that during a "Hot" period, they will not be able to gamble as the casino will not let them in.

Smaller serving sizes can also be thought of as a pre-commitment device. In an online experiment, when given a choice, many smokers preferred smaller pack sizes, even at a $25 \%$ price premium, and some explained that it was so that they could reduce future opportunities to smoke. Similarly, smaller serving sizes have been shown to reduce food consumption. Governments could limit the allowable size of sugary soft drinks as well as the pack size. Both of these highlight issues around libertarian paternalism - policies that push people toward healthy behavior (World Bank, 2015).

Pharmacological pre-commitment devices are a clear example of how people can limit future intake. There are drugs that will make someone feel ill if they drink alcohol. A person can take an anti-alcohol drug in the morning, during a "Cold" period to prevent themselves from drinking after work (when they know they will be in a "Hot" period).

Finally, new and interesting literature shows that financial pre-commitments have great potential. Using these devices, people bet their own money that they can improve their behavior: they put some money in an account and agree that 


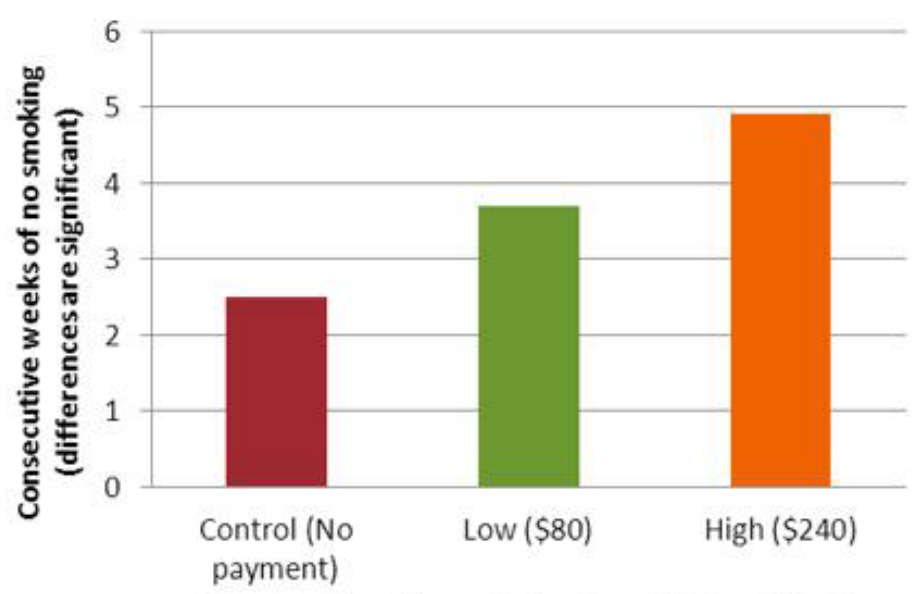

Payment Level (expected value of lottery ticket)

Figure 2: Probabilistic Incentives: Weeks absent from drug use for differential payments by treatment groups: no payments, lower probability payments, and higher probability payments..

if they have not quit at a specific point, they will lose their money (Gine, Karlan, and Zinman, 2010). People in the United States have voluntarily put over $\$ 18,000,000$ on the line as precommitment devices to help them meet their goals on StickK, a private sector website. This shows that there are a substantial number of people who are sophisticated about their self-control issues and eager for a mechanism to help them achieve their goals.

\section{Concrete opportunities for behavioral economics insights to inspire policies}

Opportunities for Pre-commitment: Providing people with opportunities to precommit may be helpful. For example, the government could subsidize the development and availability of precommitments (such as the drugs discussed above), or borrow ideas from private sector initiatives like StickK.

More and Smarter Incentives: Making incentives salient, and using more financial incentives in treatment programs, and structuring them with loss aversion, lotteries, and a focus on process as well as outcomes may yield substantial gains.

Messaging and Reminders as Public and Private Policy. As indicated above, text messaging is an approach that is now feasible due to the low cost of testing and the ubiquity of cell phones. It would be relatively cheap to provide programs where people could enroll to receive text reminders to help them through their "Hot" periods, and this may help many people change their behavior.
Establish 'Nudge Units': The UK, Australia, and the U.S. have established units to test and use findings and insights from behavioral economics to improve policies and regulations. Other countries could consider this as well.

Test and Evaluate Rigorously: Rigorous testing including, randomized treatment assignment, can help identify the most effective policies and unanticipated side effects, as well as modifications to existing policies. For example, a large ongoing randomized field study is examining the effectiveness of financial incentives in helping low income smokers (Medicaid recipients) stop smoking in the U.S.

\section{References}

Alessi, S. and N. Petry (2014). Smoking Reductions and Increased Self-efficacy in a Randomized Controlled Trial of Smoking Abstinence-Contingent Incentives in Residential Substance Abuse Treatment Patients. Official Journal of the Society for Research on Nicotine and Tobacco.

Bernheim, B. D., and Rangel, A. (2004). Addiction and cuetriggered decision processes. American Economic Review, 1558-1590.

Chetty, R., A. Looney and K. Kroft (2009). "Salience and Taxation: Theory and Evidence." American Economic Review, 99(4): 1145-77.

Eriksen M, Mackay J, Ross H. (2012) The Tobacco Atlas. Fourth Ed. Atlanta, GA: American Cancer Society; New York, NY: World Lung Foundation. Also available at www.TobaccoAtlas.org).

Free C., et al. (2011) Smoking Cessation Support Delivered via Mobile Phone Text Messaging (text2stop): A Single-blind, Randomized Trial. Lancet, 378(9785):49-55.

Giné, X., D. Karlan and J. Zinman (2010). Put your money where your butt is: a commitment contract for smoking cessation. American Economic Journal: Applied Economics 2:213-235.

Remler, D. (2004). Poor smokers, poor quitters, and cigarette tax regressivity. American Journal of Public Health 94.2: 225-229.

Sindelar, J., B. Elbel and N. Petry (2007). What do we get for our money? Cost-effectiveness of adding contingency management. Addiction 102(2):309-16.

Sindelar, J. and S. O'Malley (2014). "Financial versus health motivation to quit smoking: a randomized field study." Preventive Medicine, 59: 1-4.

Volpp, K. G., et al. (2008). Financial incentive-based approaches for weight loss: a randomized trial. Jama, 300(22), 2631-2637.

World Bank (2015). World Development Report 2015: Mind, Society, and Behavior. Washington, DC: World Bank. doi: 10.1596/978-1-4648-0342-0.

\section{SciencesPo. LIEPP}

Le Laboratoire interdisciplinaire d'évaluation des politiques publiques (LIEPP)

est un laboratoire d'excellence (labex) financé par l'ANR (ANR-11-LABX-0091, ANR-11-IDEX-0005-02).

27 rue St Guillaume, 75007 Paris - +33(0)1.45.49.83.61 - liepp@sciencespo.fr - www.sciencespo.fr/liepp

Directeurs de publication : B. Palier \& E. Wasmer - Maquette : A. Biotteau and M. Abbott - C LIEPP 2014 